Original Article

\title{
Revision of some mensural measurements, food preference, and haematological parameters in breeding pairs of blue rock pigeon, Columba livia sampled from punjab Pakistan
}

\author{
Revisão de algumas medidas mensurais, preferência alimentar e parâmetros \\ hematológicos em pares de criação de pombo blue rock (Columba livia), amostragem \\ de punjab, Paquistão

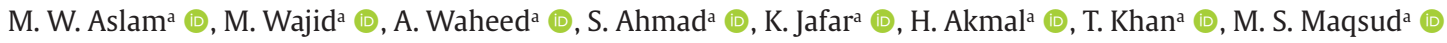 \\ and M. S. Khan ${ }^{\text {** }}$ (1) \\ aUniversity of Okara, Faculty of Life Sciences, Department of Zoology, Okara, Pakistan
}

\begin{abstract}
The present study describes the haematological profile, feeding preference, and comparison of morphometric characters of blue rock pigeon (Columba livia) breeding pairs. For this purpose, 25 pairs ( 25 samples per sex) were sampled through Mist nets from district Okara and Bahawalnagar, Punjab, Pakistan. Birds were then anaesthetized with a combination of ketamine HCL $(10 \mathrm{mg} / \mathrm{kg})$ and diazepam $(0.2 \mathrm{mg} / \mathrm{kg})$ and subjected to morphometric measurements. $5 \mu \mathrm{L}$ blood also was taken from the jugular vein of each anaesthetized bird for haematological analysis. Few pairs were also dissected to remove gastrointestinal tracts (GITs) for food preferences. Results revealed that there are no significant differences in the haematological parameters and feeding preference of breeding pairs of Columba livia. The gut analysis further revealed, the major portion of gut contents consisted of pea and corn in most of the pairs. Regarding the mensural measurements, significant differences were recorded in the body weight, length of the longest primary feather, and chest circumference, whereas the rest of the studied parameters remain nonsignificant between sexes. So, it is concluded that apart from 3 morphometric parameters (body weight, length of longest primary feather and chest circumference), both sexes are alike in term of morphometry, haematology and food preference.
\end{abstract}

Keywords: Columba livia, feeding preference, haemotology, biometrics, Pakistan.

\begin{abstract}
Resumo
O presente estudo descreve o perfil hematológico, a preferência alimentar e a comparação de caracteres morfométricos de casais reprodutores de pombo-rocha (Columba livia). Para tanto, 25 pares (25 amostras por sexo) foram amostrados por meio de redes de névoa do distrito de Okara e Bahawalnagar, Punjab, Paquistão. As aves foram então anestesiadas com uma combinação de cetamina HCL (10 mg/kg) e diazepam (0,2 mg/kg) e submetidas a medidas morfométricas; $5 \mu \mathrm{L}$ de sangue também foram retirados da veia jugular de cada ave anestesiada para análise hematológica. Poucos pares também foram dissecados para remover o trato gastrointestinal (GITs) para preferências alimentares. Os resultados revelaram que não há diferenças significativas nos parâmetros hematológicos e na preferência alimentar dos casais reprodutores de Columba livia. A análise intestinal revelou ainda que a maior parte do conteúdo intestinal consistia em ervilha e milho na maioria dos pares. Em relação às medidas mensurais, foram registradas diferenças significativas no peso corporal, comprimento da pena primária mais longa e circunferência torácica, enquanto os demais parâmetros estudados permanecem não significativos entre os sexos. Assim, conclui-se que além de três parâmetros morfométricos (peso corporal, comprimento da pena primária mais longa e circunferência torácica), ambos os sexos são semelhantes em termos de morfometria, hematologia e preferência alimentar.
\end{abstract}

Palavras-chave: Columba livia, preferência alimentar, hematologia, biometria, Paquistão.

\section{Introduction}

The blue rock pigeon is a common bird throughout its range, which includes Bhutan, Nepal, India, Bangladesh, and Pakistan. This bird species is also observed in western and southern Europe and North Africa (Ali and Ripley, 1983). In Pakistan, blue rock pigeons are found all around the country, except on the high plateaus and in the desert

*e-mail: samiikhan@uo.edu.pk

Received: May 11, 2021 - Accepted: June 18, 2021

This is an Open Access article distributed under the terms of the Creative Commons Attribution License, which permits unrestricted use, distribution, and reproduction in any medium, provided the original work is properly cited. 
areas (Gibbs et al., 2001; Robert, 1991). They are also adapted to man-made structures such as bridges with emerald straps, long concrete plates, and brick or stone buildings (Ali et al., 2013; Haag, 1988; Sacchi et al., 2002).

A clinical haematological profile is necessary for the evaluation of the health profile of any organism (Pavlak et al., 2005). This clinical technique is used to evaluate avian activity, the health, and the physical state of living organisms (Tras et al., 2000). Many studies on the haematology of the blue rock pigeon have been published. Khan et al. (2011) described normal values of complete blood count, (Gayathri and Hegde, 1994) reported some sexual differences in haematology, Gylstorff (1983) reported the effect of age on haematology, and Pavlak et al. (2005) reported haematological differences related to age, gender, and season in blue rock pigeon. This technique may also aid in the management and improvement of pigeon breeding or the breeding program (Král and Suchý, 2000). As a result, the goal of this study is to establish a reference value for haematological parameters.

The blue rock pigeon is considered 'granivorous' in feeding and is closely related to human settlements due to its domestic origin. The birds are diurnal foragers who fly in large flocks and travel about 3-8 km per day in search of food. They also damage food crops while collecting grains (Baldaccini et al., 2000). These grains are from cereal crops, brassica, lentils, chickpea, and mug beans (Robert, 1991). They also feed on the seeds of trees, herbs, millet, and ground net (Ibrahim and Abdu, 1992).

Morphometry is a general technique to identify and distinguish between the sexes of the same species. It also gives information related to the age, status and size of birds (Leisler, 1972). The physical measurement of wings and tails is important in the monitoring of flight as well as the migratory patterns of some birds. They also describe the flight characteristics and energetics of birds (Pilastro et al., 1995). Morphometric measurement can also be used for scientific study, e.g. sex differences, geological separation of the same species, and for the other characteristics of birds (Töpfer, 2018).

The main objective of our study was to report the haematological profile, feeding preference, and morphometry of blue rock pigeon samples from Punjab, Pakistan, and to provide standard reference haematological and morphometric values for studies to be conducted in the future.

\section{Material and Methods}

\subsection{Sample areas}

Blue rock pigeons (25 samples per sex) were sampled from cultivable fields through mist nets from the districts of Okara ( $31^{\circ} 05^{\prime} 51.0^{\prime \prime} \mathrm{N} 73^{\circ} 32^{\prime} 36.0^{\prime \prime} \mathrm{E}$; $31^{\circ} 02^{\prime} 31.0^{\prime \prime} \mathrm{N}$ $73^{\circ} 35^{\prime} 38.0^{\prime \prime} \mathrm{E} ; 31^{\circ} 02^{\prime} 18.0^{\prime \prime} \mathrm{N} 73^{\circ} 31^{\prime} 20.0^{\prime \prime} \mathrm{E}$ ) and Bahawalnagar (30¹2'12.0”N 7343'17.0”E), Punjab, Pakistan. This area is semi-dry, with temperature ranges of between $15-25^{\circ} \mathrm{C}$ and $16-26^{\circ} \mathrm{C}$ respectively, especially in the winter season. The sampling was done between December 2018 to March 2019.

\subsection{Morphometry}

After capturing, the birds were anaesthetized with a combination of ketamine $\mathrm{HCL}(10 \mathrm{mg} / \mathrm{kg}$ ) and diazepam $(0.2 \mathrm{mg} / \mathrm{kg})$ and subjected to morphometric measurements. Body weight was taken by using an electronic balance $(0.001 \mathrm{~g})$. Body length, wingspan, wing length, length of the longest primary feather, tail length, tarsus, central toe length, chest circumference, bill size, and head size were recorded according to Eck et al. (2012) and Semakula et al. (2011).

\subsection{Sample collection and haematological analysis}

For haematology, $5 \mu \mathrm{L}$ blood was also taken from the jugular vein in an EDTA tube of each anaesthetized bird. An automatic haematological analyzer was used for the haematological profile. The recorded haematological parameters included haemoglobin concentration $(\mathrm{Hb})$, White blood cells (WBCs) counts, Red blood cells (RBCs) counts, Packed cell volume (PCV), Mean corpuscular volume (MCV), Mean corpuscular haemoglobin (MCH), Mean corpuscular haemoglobin concentration (MCHC), platelets, Red cell distribution width (RDW), Platelet distribution width (PDW), Mean platelet volume (MPV), Neutrophils, Lymphocyte, Monocyte, and Eosinophil. Animal ethics were ensured by all means.

\subsection{Feeding analysis}

Few pairs were also dissected to remove gastrointestinal tracts (GITs) for food preferences. Each gastrointestinal tract was stored in a $30 \%$ formalin solution. Each stomach was dissected to remove the food contents, washed properly and identified using a dissecting microscope (2-4X, IRMECO) with the help of descriptions and diagrams available for seed identification (Martin and Barkley, 1961).

\subsection{Statistical analysis}

The data was described using standard statistical methods, including means, SE, and range (SPSS v21). The significant difference was tested through an unpaired t-test at a 0.05 confidence level.

\section{Results}

The results of haemotology showed non-significant differences in all parameters between male and female blue rock pigeon (Table 1 ).

Gut analysis also showed a non-significant difference in the weight of total food material, grains, pebbles, and digested material in both sexes (Table 2). However, the percentage of each type of food material was slightly different in male and female blue rock pigeon (Table 3 ).

The body weight, length of the longest primary feather, and chest circumference were the morphometric parameters that differed significantly in male and female (Figure 1 and Figure 2) while rest of the parameters were non-significant between breeding pairs (Table 4 ). 
Table 1. Haematological profile of male and female blue rock pigeon.

\begin{tabular}{|c|c|c|c|c|c|}
\hline \multirow{3}{*}{ Parameters } & Gender & \multirow{3}{*}{ Mean } & \multirow{3}{*}{ Range } & \multirow{3}{*}{ SE } & \multirow{3}{*}{ p-value } \\
\hline & $\mathrm{n}=\mathbf{2 5}$ & & & & \\
\hline & from each sex & & & & \\
\hline \multirow{2}{*}{$\mathrm{Hb}(\mathrm{g} / \mathrm{dl})$} & Male & 21.57 & $19.4-23.9$ & 1.06 & \multirow{2}{*}{$0.5301^{\mathrm{NS}}$} \\
\hline & Female & 22.93 & $20.7-25.8$ & 1.23 & \\
\hline \multirow{2}{*}{ WBCs $\left({ }^{\times} 10^{3} / \mathbf{u l}\right)$} & Male & 386.33 & $383-390$ & 1.66 & \multirow{2}{*}{$0.5406^{N}$} \\
\hline & Female & 384.67 & $382-387$ & 1.19 & \\
\hline \multirow{2}{*}{$\begin{array}{c}\text { Total RBCs } \\
\text { (million/cmm) }\end{array}$} & Male & 3.27 & $2.5-3.7$ & 0.31 & \multirow{2}{*}{$0.8098^{\mathrm{N}}$} \\
\hline & Female & 3.13 & $2.5-3.7$ & 0.28 & \\
\hline \multirow{2}{*}{ HCT/PCV (\%) } & Male & 53.80 & $52.2-55.1$ & 0.69 & \multirow{2}{*}{0.8914 Ns } \\
\hline & Female & 53.63 & $52.5-55.1$ & 0.63 & \\
\hline \multirow{2}{*}{$\operatorname{MCV}(\mathbf{f l})$} & Male & 15.67 & 13-19 & 1.44 & \multirow{2}{*}{0.9999 N } \\
\hline & Female & 15.67 & $13-18$ & 1.19 & \\
\hline \multirow{2}{*}{ MCH (\%) } & Male & 59.63 & $56.3-63.2$ & 1.63 & \multirow{2}{*}{0.4465 № } \\
\hline & Female & 57.47 & $54.6-60.2$ & 1.32 & \\
\hline \multirow{2}{*}{ MCHC (\%) } & Male & 38.17 & $34.5-40.5$ & 1.52 & \multirow{2}{*}{$0.894^{\mathrm{NS}}$} \\
\hline & Female & 38.47 & $36.7-40.2$ & 0.83 & \\
\hline \multirow{2}{*}{ Plateletes $\left({ }^{\times} 10^{3} / \mathrm{ul}\right)$} & Male & 16.33 & $13-20$ & 1.66 & \multirow{2}{*}{$0.9001^{\mathrm{N} s}$} \\
\hline & Female & 16.67 & $14-19$ & 1.19 & \\
\hline \multirow{2}{*}{ RDW (fl) } & Male & 45.87 & $43.7-47.5$ & 0.92 & \multirow{2}{*}{0.8356 Ns } \\
\hline & Female & 45.47 & $43.5-48.2$ & 1.15 & \\
\hline \multirow{2}{*}{ PDW (fl) } & Male & 16.83 & $14.6-19.7$ & 1.23 & \multirow{2}{*}{0.1483 Ns } \\
\hline & Female & 13.70 & $12.1-15.2$ & 0.73 & \\
\hline \multirow{2}{*}{$\operatorname{MPV}(\mathbf{f l})$} & Male & 12.00 & 9-16 & 1.70 & \multirow{2}{*}{0.41 Ns } \\
\hline & Female & 14.33 & $12-17$ & 1.19 & \\
\hline \multirow{2}{*}{ Neutrophils (\%) } & Male & 84.67 & $83-86$ & 0.72 & \multirow{2}{*}{0.2417 Ns } \\
\hline & Female & 82.33 & $80-85$ & 1.19 & \\
\hline \multirow{2}{*}{ Lymphocytes (\%) } & Male & 8.00 & $7-8$ & 0.47 & 03465 NS \\
\hline & Female & 6.33 & $4-9$ & 1.19 & 0.3465 \\
\hline Monocites (\%) & Male & 2.00 & $1-2$ & 0.47 & 07217 NS \\
\hline Ronocytes (\%) & Female & 2.33 & $1-3$ & 0.54 & $0.124 / 7$ \\
\hline Fosinonhils $(\%$ & Male & 2.33 & $2-2$ & 0.27 & O 6779 NS \\
\hline Eosinophils (\%) & Female & 2.67 & $2-4$ & 0.54 & $0.6 / 79^{103}$ \\
\hline
\end{tabular}

NS $=$ Non-significant $(\mathrm{P}>0.05) ; \mathrm{SE}=$ Standard error.

Table 2. Comparisons of different feeding content in male and female blue rock pigeon.

\begin{tabular}{|c|c|c|c|c|c|c|c|}
\hline Types of food & Gender & $\mathbf{N}$ & Mean & SD & SE & t-value & P-value \\
\hline \multirow{2}{*}{ Total weight of gut (g) } & Male & 25 & 9.17 & 1.31 & 0.46 & \multirow{2}{*}{0.09} & \multirow{2}{*}{$0.932^{\mathrm{NS}}$} \\
\hline & Female & 25 & 9.12 & 0.87 & 0.31 & & \\
\hline \multirow{2}{*}{ Weight of empty gut (g) } & Male & 25 & 6.73 & 0.87 & 0.31 & \multirow{2}{*}{0.32} & \multirow{2}{*}{$0.753^{\mathrm{NS}}$} \\
\hline & Female & 25 & 6.50 & 0.60 & 0.21 & & \\
\hline \multirow{2}{*}{ Weight of total food material (g) } & Male & 25 & 2.44 & 0.49 & 0.17 & \multirow{2}{*}{-0.17} & \multirow{2}{*}{$0.869^{\mathrm{NS}}$} \\
\hline & Female & 25 & 2.62 & 0.37 & 0.13 & & \\
\hline \multirow{2}{*}{ Weight of grains ( $\mathrm{g}$ ) } & Male & 25 & 0.66 & 0.18 & 0.06 & \multirow{2}{*}{0.01} & \multirow{2}{*}{$0.989^{\text {NS }}$} \\
\hline & Female & 25 & 0.59 & 0.44 & 0.15 & & \\
\hline \multirow{2}{*}{ Weight of pebbles (g) } & Male & 25 & 0.60 & 0.06 & 0.02 & \multirow{2}{*}{-0.11} & \multirow{2}{*}{$0.912^{\mathrm{N}}$} \\
\hline & Female & 25 & 0.72 & 0.37 & 0.13 & & \\
\hline \multirow{2}{*}{ Weight of digested material $(\mathrm{g})$} & Male & 25 & 1.22 & 0.80 & 0.28 & \multirow{2}{*}{0.11} & \multirow{2}{*}{$0.917^{\mathrm{NS}}$} \\
\hline & Female & 25 & 1.02 & 0.21 & 0.07 & & \\
\hline
\end{tabular}

$\mathrm{SD}=$ Standard deviation; $\mathrm{SE}=$ Standard error. 


\section{Discussion}

Although our study did not show any significant differences in breeding pairs of Columba livia, however, the mean values of haemoglobin concentration, $\mathrm{MCH}, \mathrm{MCV}$ and MCH were found to be higher than Khan et al. (2011). Further, the numbers of total WBCs were significantly lower (383000-390000) than the findings of Khan et al. (2011) (860000-5320000). The remaining parameters are reported for the first time in the present study. The haematological profile is critical for monitoring the health of living organisms (Prinzinger and Misovic, 2010). Ihedioha et al. (2016) described no significant difference in hemoglobin concentration of male and female domestic pigeon. However, they found significant differences in other haematological parameters (PCV, heterophil, monocytes, basophils, lymphocytes and eosinophil).

The values of haematological profiles such as RBCs and WBCs and their parameters are high in pigeons as compared to other avian species, but these values are related to ducks and domestic fowls (Gayathri and Hegde, 1994). This occurred due to the high metabolic rate and powerful flight of the pigeons. Many studies reported that haematological profiles in the non-breeding season

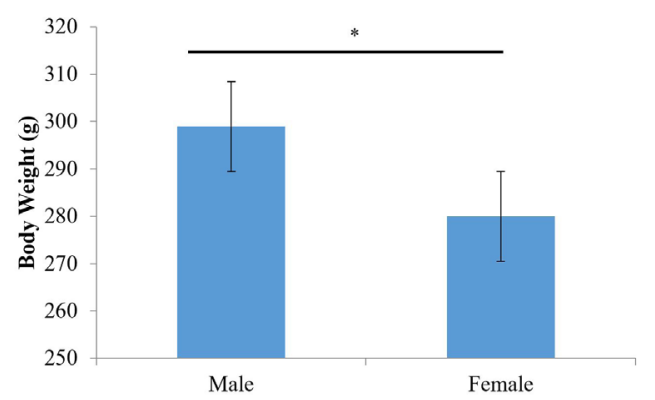

Figure 1. Comparison of body weight between male and female blue rock pigeon $\left({ }^{*}=\mathrm{p}<0.05\right)$ are significantly high because of many hormonal actions as well. Prolactin was also higher in the blood plasma of nonbreeding male pigeons than in females (Hall et al., 1986).

Blue rock pigeons are granivorous in nature. They have adapted themselves to living in a man-made structure. From the present study, it is concluded that Columba livia feeds on different types of grains and pebbles. Corn, maize, peas, wheat, and rice are among the grains consumed by the Columba livia. Pebbles were also observed in the GIT. They used small pebbles for the grinding, breaking down and digestion of large-sized grains. Our study was supported Ali and Ripley (1983), Batool et al. (2020), Kaur and Dhanju (2013) and Robert (1991).

Body weight, body length, tail length, wingspan, length of the longest primary feather, chest circumference, head size, bill length, tarsus, and central toe length were the parameters described in the current study for blue rock pigeon morphometric analysis. The average body weight of an adult blue rock pigeon was $298.88 \pm 10.26$ in male and $280 \pm 17.43$ in females that were similar to the results described by Bhowmik et al. (2014) and Hena et al. (2012).

Table 3. Percentage of different type of grains and pebbles in all samples.

\begin{tabular}{lcc}
\hline \multirow{2}{*}{ Type of Food } & \multicolumn{2}{c}{$\begin{array}{c}\text { Percentage by weight of food } \\
\text { material (\%) }\end{array}$} \\
\cline { 2 - 3 } & Male (n=25) & Female (n=25) \\
\hline Pebbles & 23.68 & 30.78 \\
Corn & 10.28 & 12.31 \\
Pea & 13.29 & 11.21 \\
Rice & 1.30 & 0.61 \\
Wheat & 1.77 & 1.24 \\
Rice husk & 0.33 & 0.00 \\
Digested material & 49.34 & 43.86 \\
\hline
\end{tabular}

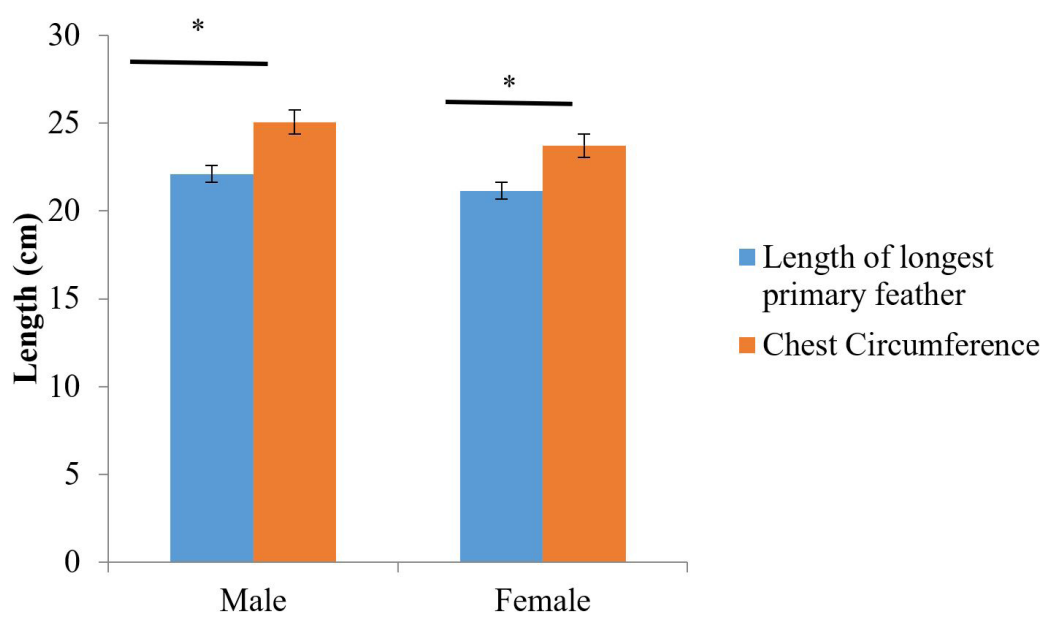

Figure 2. Comparison of length of the longest primary feather and chest circumference between male and female blue rock pigeon $(*=p<0.05)$ 
Table 4. Comparisons in morphometry of male and female blue rock pigeon.

\begin{tabular}{|c|c|c|c|c|c|}
\hline \multirow[b]{2}{*}{ Characters } & Gender & \multirow[b]{2}{*}{ Mean } & \multirow[b]{2}{*}{ Range } & \multirow[b]{2}{*}{ SE } & \multirow[b]{2}{*}{ P-value } \\
\hline & $\begin{array}{c}n=25 \\
\text { from each }\end{array}$ & & & & \\
\hline \multirow{2}{*}{ Body Weight (g) } & Male & 298.88 & $275-310$ & 3.36 & \multirow{2}{*}{$0.0270^{*}$} \\
\hline & Female & 280 & $252-308$ & 6.16 & \\
\hline \multirow{2}{*}{ Body Length (cm) } & Male & 32.91 & $31.7-34.5$ & 0.31 & \multirow{2}{*}{$0.4217^{\mathrm{NS}}$} \\
\hline & Female & 32.51 & $31-34$ & 0.33 & \\
\hline \multirow{2}{*}{ Wingspan $(\mathrm{cm})$} & Male & 62.24 & $58.4-65.7$ & 0.88 & \multirow{2}{*}{0.3322 Ns } \\
\hline & Female & 60.98 & $56.7-64.6$ & 0.77 & \\
\hline \multirow{2}{*}{ Wing length $(\mathrm{cm})$} & Male & 26.23 & $23.5-28.1$ & 0.46 & \multirow{2}{*}{0.7229 Ns } \\
\hline & Female & 26.45 & $24.7-27.9$ & 0.36 & \\
\hline \multirow{2}{*}{ Length of longest primary feather $(\mathrm{cm})$} & Male & 22.11 & $21-23.2$ & 0.23 & \multirow{2}{*}{$0.0164^{*}$} \\
\hline & Female & 21.14 & $20.3-22.6$ & 0.24 & \\
\hline \multirow{2}{*}{ Chest circumference $(\mathrm{cm})$} & Male & 25.05 & $24-27$ & 0.38 & \multirow{2}{*}{$0.0139^{*}$} \\
\hline & Female & 23.70 & $23-25$ & 0.24 & \\
\hline \multirow{2}{*}{ Head size $(\mathrm{cm})$} & Male & 6.4 & $4.4-7.4$ & 0.92 & \multirow{2}{*}{$0.2218^{\mathrm{NS}}$} \\
\hline & Female & 5.9 & $5.2-6.8$ & 0.26 & \\
\hline \multirow{2}{*}{ Bill length $(\mathrm{cm})$} & Male & 2.76 & $1.4-3.4$ & 0.24 & \multirow{2}{*}{$0.3815^{\mathrm{NS}}$} \\
\hline & Female & 2.49 & $1.9-3.4$ & 0.15 & \\
\hline \multirow{2}{*}{ Tarsus $(\mathrm{cm})$} & Male & 3.10 & $2.4-3.7$ & 0.12 & \multirow{2}{*}{0.7432 Ns } \\
\hline & Female & 3.16 & $2.7-3.8$ & 0.12 & \\
\hline \multirow{2}{*}{ Central toe length $(\mathrm{cm})$} & Male & 3.74 & $3.1-4.6$ & 0.15 & \multirow{2}{*}{0.2184 NS } \\
\hline & Female & 3.51 & $3.2-3.8$ & 0.06 & \\
\hline \multirow{2}{*}{ Tail Length $(\mathrm{cm})$} & Male & 11.15 & $9-12.7$ & 0.40 & \multirow{2}{*}{0.7861 Ns } \\
\hline & Female & 11.01 & $9.8-11.8$ & 0.23 & \\
\hline
\end{tabular}

NS $=$ Non-significant $(\mathrm{P}>0.05) ; \mathrm{SE}=$ Standard error; ${ }^{*}=$ Significant $(\mathrm{P}<0.05)$.

The average wing length in our study was $26.23 \pm 1.29$ for male and $26.45 \pm 1.02$ for females which were also supported by Ali and Ripley (1983) and Vaurie (1965). The outcomes of our study were also similar to Robert (1991) in the case of body length, bill length, wingspan and tail length, while the remaining morphometric parameters in our study were reported for the very first time.

\section{Conclusion}

This study revealed no significant difference in feeding contents and haematological profile in breeding pairs of blue rock pigeon. Only body weight, length of the longest primary feather and chest circumference were significantly different. Both sexes showed same feeding preferences for grains and seeds.

\section{References}

ALI, S. and RIPLEY, D., 1983. Handbook of the Birds of India and Pakistan. 2nd ed. New Delhi: Oxford University Press. Stone Curlews to Owls, no. 3.
ALI, S., RAKHA, B.A., HUSSAIN, I., NADEEM, M.S. and RAFIQUE, M., 2013. Ecology of feral pigeon (Columba livia) in urban areas of Rawalpindi/Islamabad, Pakistan. Pakistan Journal of Zoology, vol. 45, no. 5, pp. 1229-1234.

BALDACCINI, N.E., GIUNCHI, D., MONGINI, E. and RAGIONIERI, L., 2000. Foraging flights of wild rock doves (Columba l. livia): a spatio-temporal analysis. The Italian Journal of Zoology, vol. 67, no. 4, pp. 371-377. http://dx.doi.org/10.1080/11250000009356342.

BATOOL, F., KHAN, H. and REHMAN, M., 2020. Feeding ecology of blue rock pigeon (Columba livia) in the three districts of Punjab, Pakistan. Brazilian Journal of Biology $=$ Revista Brasileira de Biologia, vol. 80, no. 4, pp. 881-890. http://dx.doi. org/10.1590/1519-6984.225451. PMid:31800769.

BHOWMIK, N., MIA, M. and RAHMAN, M., 2014. Morphometric measurements, productive and reproductive performance of Jalali pigeon. International Journal of Development Research, vol. 4, no. 4, pp. 908-911.

ECK, S., FIEBIG, J., FIEDLER, W., HEYNEN, I., NICOLAI, B., TÖPFER, T., VAN DEN ELZEN, R., WINKLER, R. and WOOG, F., 2012. Measuring birds. Wilhelmshaven: Deutsche Ornithologen-Gesellschaft.

GAYATHRI, K. and HEGDE, S., 1994. Sexual differences in blood values of the pigeon, Columba livia. Comparative Biochemistry and Physiology Part B: Comparative Biochemistry, vol. 109, no. 2-3, pp. 219-224. http://dx.doi.org/10.1016/0305-0491(94)90005-1. 
GIBBS, D., BARNES, E. and COX, J., 2001. Pigeons and doves: a guide to the pigeons and doves of the world. London: A\&C Black, $615 \mathrm{p}$.

GYLSTORFF, I., 1983. Blut, blutbildung und blutkreislauf. Handbuch der Geflügelphysiologie, vol. 1, pp. 280-393.

HAAG, D., 1988. Die dichteabhängige Regulation im Brutschwarm der Strassentaube Columba livia forma domestica. Der Ornithologische Beobachter, vol. 85, pp. 209-224.

HALL, T., HARVEY, S. and CHADWICK, A., 1986. Control of prolactin secretion in birds: a review. General and Comparative Endocrinology, vol. 62, no. 2, pp. 171-184. http://dx.doi. org/10.1016/0016-6480(86)90107-3. PMid:2877915

HENA, S., SONFADA, M., DANMAIGORO, A. and BELLO, A., 2012. Comparative weight assessment of some visceral organs in adult pigeon (Columbia livia) and Japanese quail (Coturnix japonica). Scientific Journal of Zoology, vol. 229, no. 1303, pp. 1-6.

IBRAHIM, M. and ABDU, P., 1992. Ethno agro-veterinary perspectives of poultry management, health and production among the Hausa/Fulani of rural Nigeria. In: Proceedings of 29th Annual General Meeting of Nigerian Veterinary Medicine Association, 1992, Kaduna, Nigeria. Abuja: NVMA, pp. 172-181.

IHEDIOHA, J.I., ANYOGU, D.C. and CHIBUEZEOKE, K.J., 2016. Haematological profile of the domestic pigeon (Columba livia domestica) in Nsukka agro-ecological zone, Enugu state, Nigeria. Animal Research International, vol. 13, no. 1, pp. 2368-2377.

KAUR, N. and DHANJU, C., 2013. Food and feeding habits of common birds of agroecosystems. Indian Ecol Soc, vol. 40, pp. 83-86.

KHAN, B.Y.A., ALI, F., SAEED, M.Q., ASGHAR, M. and IQBAL, F., 2011. A study on serum biochemistry and hematological profiling of blue rock pigeon (Columba livia) in Multan (Punjab, Pakistan). Pakistan Journal of Zoology, vol. 43, no. 5, pp. 1012-1014.

KRÁL, I. and SUCHÝ, P., 2000. Haematological studies in adolescent breeding cocks. Acta Veterinaria Brno, vol. 69, no. 3, pp. 189-194. http://dx.doi.org/10.2754/avb200069030189.

LEISLER, B., 1972. Artmerkmale am Fuß adulter Teich-und Sumpfrohrsänger (Acrocephalus scirpaceus, A. palustris) und ihre Funktion. Journal für Ornithologie, vol. 113, no. 4, pp. 366373. http://dx.doi.org/10.1007/BF01647600.

MARTIN, A.C. and BARKLEY, W.D., 1961. Seed identification manual. Berkeley: University of California Press, 221 p.
PAVLAK, M., VLAHOVIĆ, K., JERČIĆ, J., DOVČ, A. and ŽUPANČIĆ, Ž., 2005. Age, sexual and seasonal differences of haematological values and antibody status to Chlamydophila sp. in feral and racing pigeons (Columba livia forma domestica) from an urban environment (Zagreb, Croatia). European Journal of Wildlife Research, vol. 51, no. 4, pp. 271-276. http://dx.doi.org/10.1007/ s10344-005-0110-3.

PILASTRO, A., FARRONATO, I. and FRACASSO, G., 1995. The use of feather length as a method for measuring the wing shape of passerines. Avocetta, vol. 19, pp. 213-218.

PRINZINGER, R. and MISOVIC, A., 2010. Age-correlation of blood values in the Rock Pigeon (Columba livia). Comparative Biochemistry and Physiology. Part A, Molecular E Integrative Physiology, vol. 156, no. 3, pp. 351-356. http://dx.doi. org/10.1016/j.cbpa.2009.07.028. PMid:20184962.

ROBERT, T., 1991. The birds of Pakistan. Oxford: Oxford University Press, $598 \mathrm{p}$.

SACCHI, R., GENTILLI, A., RAZZETTI, E. and BARBIERI, F., 2002. Effects of building features on density and flock distribution of feral pigeons Columba livia var. domestica in an urban environment. Canadian Journal of Zoology, vol. 80, no. 1, pp. 48-54. http:// dx.doi.org/10.1139/z01-202.

SEMAKULA, J., LUSEMBO, P., KUGONZA, D., MUTETIKKA, D., SSENNYONJO, J. and MWESIGWA, M., 2011. Estimation of live body weight using zoometrical measurements for improved marketing of indigenous chicken in the Lake Victoria basin of Uganda. Livestock Research for Rural Development, vol. 23, no. 8, pp. 170.

TÖPFER, T., 2018. Morphological Variation in Birds: Plasticity, Adaptation, and Speciation. In: D.T. TIETZE, ed. Bird species: how they arise, modify and vanish. Cham: Springer International Publishing, pp. 63-74. http://dx.doi.org/10.1007/978-3-319-91689-7_4.

TRAŞ, B., INAL, F., BAS, A., ALTUNOK, V., ELMAS, M. and YAZAR, E., 2000. Effects of continuous supplementations of ascorbic acid, aspirin, vitamin E and selenium on some haematological parameters and serum superoxide dismutase level in broiler chickens. British Poultry Science, vol. 41, no. 5, pp. 664-666. http://dx.doi.org/10.1080/00071660020009225. PMid:11201449.

VAURIE, C., 1965. The birds of the palearctic fauna: a systematic reference, non-passeriformes. London: HF \& G. Witherby, 763 p. 